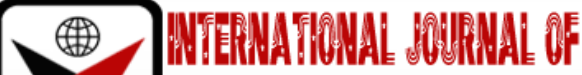

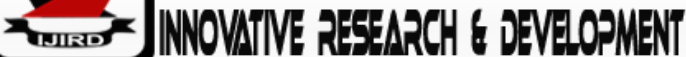

ISSN 2278-0211 (Online)

\section{Knowledge, Attitude and Practice of Voluntary Non-Remunerated Blood Donation among Medical Students of Imo State University, Owerri, Nigeria}

Ewurum, Uchechi A
Resident Doctor, Department of Anatomical Pathology,
University of Portharcourt Teaching Hospital, Nigeria
Chukukere Nneoma U
Resident Doctor, Department of Psychiatry,
Neuropsychiatric Hospital, Enugu, Nigeria
Chineke Henry N
Associate Professor, Department of Family Medicine,
Imo State University Teaching Hospital, Nigeria
Igweagu PN
Lecturer, Department of Community Medicine,
Enugu State University Teaching Hospital Parklane, Nigeria
Adogu Prosper O
Professor, Department of Community Medicine
Nnamdi Azikiwe University, Awka, Nigeria

\section{Abstract:}

Background: The need for blood is growing and its demand far exceeds the supply. The major source of safe blood is on the basis of voluntary non-remunerated blood donation (VNRBD), but the practice of VNRBD is very low probably because of poor knowledge and lack-lustre attitude towards it. This study determined the knowledge, attitude and practice of VNRBD among medical students of Imo State University (IMSU), Owerri.

Methodology: This was a descriptive cross-sectional school-based study which employed a stratified sampling technique to select participants. A semi-structured self-administered questionnaire was used to collect data on sociodemographic characteristics, knowledge, attitude and practice of VNRBD. This was analyzed using MS Excel while chi square and $\mathrm{z}$-tests of significance were employed where appropriate.

Results: Almost all the students (99.5\%) knew the correct meaning of VNRBD, 61.1\% said it was ideal and 53.1\% noted it was the safest type of blood donation. About (93.5\%) was willing to donate blood voluntarily without remuneration. Whereas $74.1 \%$ had ever donated blood, $71.4 \%$ actually did VNRBD. Also, significantly higher proportion of males than females had the correct attitude about VNRBD $(Z=3.31 ; p<0.05)$. Clinical students had more correct knowledge about VNRBD, than their preclinical counterparts. $(Z=3.54 ; p<0.05)$. More males (84.4\%) than females $(67.7 \%)$ had ever donated blood, $(p<0.05)$, and done so on the basis of VNRBD (83\% males vs $61.8 \%$ females) $(p<0.05)$.

Conclusion: Although medical students of IMSU showed high level of knowledge and positive attitude towards VNRB donation, the practice among them remained sub-optimal and hence, needs to be promoted.

Keywords: Voluntary, Non-Remunerated, Blood Donation, Practice, Clinical students

\section{Introduction}

Blood is the most donated tissue in medical practice and a veritable tool in many live-saving situations when used judiciously [1]. In spite of extensive promising research, a true substitute for blood and blood components may not be available for many years [2]. Therefore, blood donation by humans will continue to be the only source of blood and blood components. The donated blood is utilized in the life-saving practice of Blood Transfusion, which consists of the 'safe' transfer of blood components from a donor to a recipient [3]. The donor and recipient could be same (as in Autologous Blood Transfusion) or different persons whose blood is compatible (as in Homologous or Allogeneic Blood Transfusion). The latter is the major type of blood transfusion in clinical practice in Nigeria.

Historically, the use of blood as a product can be traced back to the 17th century, although the greatest advances in its therapeutic use were prompted by the worldwide conflicts of the first half of the 20th century[4]. With further 
developments in the field of transfusion medicine, concerns for safety of donated blood arose. Thus, in 1970 U.S. blood banks moved towards an all-volunteer blood donor system.

The need for blood is growing day by day as a result of the advancement in the clinical medicine[5]. In addition, increase in life expectancy, urban development and associated increase in accidents, specialized surgeries demand the usage of blood supply [6].

Every year about 234 million major operations are performed worldwide, of which 63 million people undergoing surgery for traumatic injuries, 31 million for treating cancers and another 10 million for pregnancy-related complications [7]. Worldwide, Obstetrics is a major area in medicine requiring blood transfusion. Obstetric haemorrhage remains a major cause of maternal mortality in the UK. In the UK about 4000 cases of severe obstetric haemorrhage take place each year, of which most of the patients need blood transfusion [8]. Postpartum haemorrhage, Obstructed labour, ruptured uterus, sepsis, anemia are the common causes of maternal deaths in Nigeria [9] and other sub-Saharan African countries [10]. In sub-Saharan Africa, it is estimated that $26 \%$ of maternal hemorrhagic deaths are a direct consequence of the lack of blood transfusion services, and globally up to 150,000 pregnancy-related deaths could be avoided each year if women had access to safe blood [11]. In fact, blood transfusion is recognized as one of the eight essential components of comprehensive emergency obstetric care (cEmOC), which has been shown to reduce rates of maternal mortality [11]. In newborn care where Exchange Blood Transfusion is a major therapeutic option in the management of Neonatal Jaundice the need for adequacy of blood is also very obvious.

From the foregoing, it is evident that blood transfusion and hence, need to provide adequate blood through blood donation is very sacrosanct in modern day medical practice. The only source of transfused blood is blood donation. There are 4 forms of blood donation which are autologous or self-donation; wherein people donate blood to be transfused on them either earlier before a surgery is performed on them as in pre-operative autologous blood donation and preoperative hemodilution or their blood is collected, re-filtered and transfused on them during or after an operative procedure, respectively (Intra-operative or post-operative blood salvage respectively). This is not a popular form of blood donation in Nigeria. Family replacement donation is when a replacement donor donates blood for a particular patient (relatives, friends). Blood donation here is not voluntary. Commercial or paid blood donation, in which case transfusion blood is bought from a 'blood tout'. Blood donation here although voluntary, is remunerated.

Voluntary non-remunerated blood donation: This is the donation of blood solely for altruistic reasons. Internationally, regular voluntary non-remunerated blood donors who donate blood out of altruism are considered safe blood donors. They are the ideal blood donors, hence good knowledge about uncompelled and self-initiated (voluntary) unpaid(non-remunerated) blood donation, proper attitude towards it and optimal practice of it is desirable and this study would focus on how knowledgeable medical students are about voluntary unpaid blood donation, how they feel about it, including if they desire to get involved as recruiters and the frequency of its practice and other factors affecting its practice among Imo state university medical students. Blood can save millions of lives.

The requirement of blood and blood products in a country depends on the population, health care structure, prevalence of conditions requiring regular transfusions, such as hemophilia and thalassemia etc., availability of surgical centers using modern sophisticated techniques, and awareness among clinicians regarding the judicious use of blood. However, problem regarding a permanent shortage of blood is observed in blood services all over the world [12]. The demand for blood far outweighs its supply.

In addition to limited supply, the safety especially with regard to the risk of transfusion transmissible infections like Human Immunodeficiency Virus (HIV), hepatitis, syphilis, chagas disease and malaria is also an issue of utmost concern especially in developing countries. In 2002,5\%-10\% of newly acquired HIV infections were related to infected blood transfusions. As women and children are the most likely recipients of blood in areas of both high HIV prevalence and blood supply shortages, they are at disproportionately high risk. Major source of safe blood is voluntary non-remunerated blood donors because paid donors may have high risk behaviour leading to greater chances of transfusion transmitted infections and also the family donors are under pressure may hide their high-risk behaviour and illnesses [13]. In fact, the risk of diseases transmission is highest with the use of blood procured from remunerated donors [14].

To this end, the World Health Organization advocates that member states should establish National blood transfusion service that will operate on the basis of voluntary, non-remunerable blood donation [15]. Also, the Nigerian National policy on blood advocates that blood donation should be solely voluntary and that donors should not be moribund [16].

The WHO's goal is to obtain blood supplies entirely from voluntary non-remunerated donors by 2020 and projects that $1 \%$ of the population is generally the minimum needed to meet the country's most basic requirements for blood [12]. In Nigeria, although half of the population in the country is medically fit for donation, only four in a thousand are voluntary blood donors [18] and there is still a dependency on family replacement and remunerated donors. Pundits suggest that the low practice of voluntary non-remunerated blood donation may be related to inadequate level of knowledge and lacklustre attitude towards it by Nigerians.

According to WHO, 38\% of reported voluntary blood donors are under the age of 25 years and WHO insists the countries to focus on young people to achieve $100 \%$ non-remunerated voluntary blood donation [12]. From the 6-3-3-4(63-3-6 for medical schools) educational system of Nigeria with the minimum primary school entry age of 6 , it is evident that most medical students of Imo State University would fall under the above WHO recommendation.

Medical students by virtue of being in the medical field are expected to have more knowledge about voluntary nonremunerated blood donation than non-medical students. Since medical students are respected among their peers, they could be contracted by the Nigerian National Blood Transfusion Service (NBTS) to use their expected good knowledge of voluntary non-remunerated blood donation to engage in donor recruitment at a lesser cost and a greater effectiveness if 
they have the right attitude towards voluntary non-remunerated blood donation. This would of course increase the quantity of blood gotten through voluntary non-remunerated blood donation in Nigeria.

More so, the clinical medical students are domiciled at tertiary health institutions and can serve as an ever-ready pool of safe blood donors in cases of emergencies if they have the right attitude and practice of voluntary nonremunerated blood donation. This would undoubtedly translate to greater availability of volumes of safe blood needed to save lives in cases of road traffic accidents and emergency surgical cases, help in reducing haemorrhage-related causes of maternal deaths and reduce cost of accessing health care on the predominantly poor population as they would not have to spend money to buy blood whose safety cannot be guaranteed from commercial/paid blood donors. Also, the clinical students are expected to practice voluntary non-remunerated blood donation having been exposed to the cases wherein blood transfusion saved lives and transfusion of unsafe blood led to transmission of infection.

In view of all the above, this study which intends to investigate the knowledge, attitude and practice of voluntary non-remunerated blood donation among medical students of Imo State University, Owerri is imperative as it would help in the articulation of strategies geared towards increasing the quantity of blood collected from voluntary non-remunerated blood donors. The study determined the level of knowledge, attitude and practice of voluntary non-remunerated blood donation among medical students of Imo State University, Owerri and the factors that would enhance the practice of voluntary non-remunerated blood donation among medical students would also be established.

\section{Methodology}

\subsection{Study Areas}

This study was carried out at Imo State University, Owerri campus and Orlu campus respectively. Imo State University was established in 1981 through Law No. 4 passed by the Imo State House of Assembly, Owerri. This was amended by Edict 27 of 1985, another in 1986 and finally for the relocation by the Law No. 2 of 1992 which enabled the university to be sited at its present site. It is located in Owerri; the Imo State capital, in Owerri municipal local government area of Imo State, off Okigwe road. It is a non-residential university and hence, surrounded by students hostels and also has the Cathedral of the Transfiguration of our Lord (CATOL) opposite it.

It comprises 66 departments which are unevenly distributed into 11 faculties with the faculty of Medicine and Health sciences constituting the only college of the university. The faculty of Medicine of medicine was established in 1998 and had only the Preclinical arm housed in the college of medicine and health sciences building in the main campus at Owerri. Following the completion of preclinical programme and emergence of the first set of clinical students, the need to establish a clinical section and a teaching hospital arose. Therefore, the faculty of Medicine Orlu Campus was established alongside the Imo State University Teaching Hospital, Orlu in 2003. Both are located in Umuna, a semi-urban area of Orlu which is about $35 \mathrm{~km}$ north of Owerri; the location of the main campus and the capital of Imo State-a state in the South East, Nigeria. The faculty has 8 classes ( 3 classes at Owerri and 5 classes at Orlu). The clinical students take their lectures in the lecture halls of the faculty while they undertake their clinical training at Imo State University Teaching Hospital (IMSUTH), Orlu.

IMSUTH is a tertiary health care institution which is equipped with the man-power and facilities for providing adequate health care. IMSUTH offers specialist services and post graduate training in Surgery, Obstetrics and Gynaecology, Paediatrics, Family medicine, Internal Medicine and community medicine among other specialties. Also, the accident and Emergency unit offers emergency services for all cases presenting as emergencies, herein they are resuscitated and stabilized before being moved to the appropriate department for continuation of care. IMSUTH serves as a referral hospital for both primary and secondary health care facilities within and outside the state and hence, on a daily basis, the accident and emergency department, surgery department and the obstetrics and gynaecology department get a lot of cases requiring blood transfusion.

\subsection{Study Population}

The study population included all preclinical and clinical medical students of Imo State university, Owerri obtaining their training at owerri campus and orlu campus respectively.

\subsection{Inclusion Criteria}

Only medical students who have passed their first professional examination or have passed both the first and second professional examination but have not completed their first medicine and surgery clinical postings at IMSUTH were included as Preclinical students.

Also, only medical students who have passed their second professional exam and have completed at least their first medicine and surgery postings at IMSUTH were enrolled as clinical students.

\subsection{Study Design}

The study was a descriptive cross-sectional school-based study on the knowledge, attitude and practice of voluntary non-remunerated blood donation among medical students.

\subsection{Sample Size Estimation}

The minimum sample size was determined to be 384 students using the Daniel's formula [19],proportionately distributed into the 8 classes of the faculty on Medicine. When an additional 10\% was added to make for any case of attrition, the minimum sample size used for the study became 422 students. 


\subsection{Sampling Technique}

Stratified sampling technique was employed. Samples were proportionately selected first through stratified sampling with each class constituting a stratum, then study samples from each stratum (class) were selected using simple random sampling technique with the respective class lists serving as the sampling frame.

\subsection{Data Collection}

Data was collected using pre-validated, semi-structured self-administered questionnaires.

\subsection{Data Analysis and Presentation}

Data was analyzed using simple descriptive statistical methods and data was presented using tables.

\subsection{Ethical Consideration}

Approval was sought for and secured from the department of community medicine, Imo State University, Owerri before the onset of the study and only subjects who gave an informed consent were studied.

\subsection{Limitations}

In ability to get all subjects in a particular class at the same time. This was overcome by calling the respective class representatives to know when the respective classes were together especially when they had lectures.

\section{Result}

Table 1 shows that the mean and median ages of respondents were 24 years, while the modal age was 21 years.

\begin{tabular}{|c|c|c|c|}
\hline $\begin{array}{c}\text { Variable } \\
\text { Class }\end{array}$ & $\begin{array}{c}\text { Sex } \\
\text { Male }\end{array}$ & Female & $\begin{array}{c}\text { Mean Age } \\
\text { (years) }\end{array}$ \\
\hline PC 1 & $29(61.7 \%)$ & $18(38.3 \%)$ & $20.6 \pm 2.8$ \\
\hline PC 2 & $27(46.6 \%)$ & $31(53.4 \%)$ & $21.7 \pm 2.3$ \\
\hline PC 3 & $27(47.4 \%)$ & $30(52.6 \%)$ & $22.0 \pm 2.2$ \\
\hline C 1B & $19(45.2 \%)$ & $23(54.8 \%)$ & $23.8 \pm 2.2$ \\
\hline C 1A & $27(52.9 \%)$ & $24(47.1 \%)$ & $23.9 \pm 2.0$ \\
\hline C 2B & $26(56.5 \%)$ & $20(43.5 \%)$ & $25.1 \pm 1.9$ \\
\hline C 2A & $30(62.5 \%)$ & $18(37.5 \%)$ & $27.1 \pm 1.8$ \\
\hline C 3 & $33(60 \%)$ & $22(40 \%)$ & $27.4 \pm 1.7$ \\
\hline Total & $218(54 \%)$ & $186(46 \%)$ & \\
\hline School: & & & \\
\hline Preclinical & $102(50 \%)$ & $102(50 \%)$ & $22 \pm 2.4$ \\
\hline Clinical & $116(58 \%)$ & $84(42 \%)$ & $25 \pm 1.9$ \\
\hline
\end{tabular}

Table 1: Socio Demographic Characteristics of Respondents

Also 218(54.0\%) of all the respondents were males while 186(46.0\%) of them were females. The mean ages of respondents by class ranged from 20.6 to 27.4 years. Preclinical and clinical students had mean ages of $22.0 \pm 2.4$ and $25.9 \pm 1.9$ years respectively.

\begin{tabular}{|c|c|c|}
\hline $\begin{array}{c}\text { Variables } \\
\text { Meaning of Voluntary Unpaid Blood Donation: }\end{array}$ & Frequency & Percentage \\
\hline $\begin{array}{c}\text { Donation of blood by a willing donor without } \\
\text { asking for money(N=398) }\end{array}$ & 396 & 37.9 \\
\hline $\begin{array}{c}\text { Donation of blood to be used by friends and } \\
\text { relatives }\end{array}$ & 151 & 4.0 \\
\hline $\begin{array}{c}\text { Donation of blood after payment of some money to } \\
\text { the donor }\end{array}$ & 16 & 53.1 \\
\hline $\begin{array}{c}\text { The safest type of blood donation } \\
\text { The ideal type of blood donation }\end{array}$ & 211 & 61.6 \\
\hline
\end{tabular}

Table 2: Distribution of Respondents by Knowledge of Voluntary Non-Remunerated Blood Donation

In table 2,almost all respondents (99.5\%) knew the correct meaning of VNRBD, with $61.1 \%$ recognizing it as an ideal type of blood donation and $53.1 \%$ the safest type of blood donation. 


\begin{tabular}{|c|c|c|}
\hline $\begin{array}{c}\text { Variables } \\
\text { Thoughts about Voluntary Unpaid } \\
\text { Blood Donation: }\end{array}$ & Frequency & Percentage (\%) \\
\hline Type of blood donation (N=398) & 275 & 69.1 \\
\hline It should be practiced by all & 272 & 68.3 \\
\hline Safe and lifesaving & 329 & 82.7 \\
\hline Should be encouraged & 356 & 6.8 \\
\hline $\begin{array}{c}\text { Doesn't fancy this type of blood } \\
\text { donation }\end{array}$ & 27 & 1.5 \\
\hline $\begin{array}{c}\text { People should be discouraged from } \\
\text { practicing it }\end{array}$ & 6 & 2.0 \\
\hline $\begin{array}{c}\text { Seen as dangerous type of blood } \\
\text { donation }\end{array}$ & 8 & 1.3 \\
\hline $\begin{array}{c}\text { This type of donation should be } \\
\text { abolished }\end{array}$ & 5 & 93.5 \\
\hline $\begin{array}{c}\text { Willing to donate } \\
\text { blood voluntarily without asking } \\
\text { for money if approached }\end{array}$ & 372 & \\
\hline $\begin{array}{c}\text { Would you want to be a } \\
\text { regular voluntary unpaid blood } \\
\text { donor }\end{array}$ & 227 & 57.0 \\
\hline $\begin{array}{c}\text { Willing to be trained as a recruiter of } \\
\text { VNRBDs }\end{array}$ & 227 & 57.0 \\
\hline $\begin{array}{c}\text { Willing to serve as a recruiter of } \\
\text { VNRBDs for free: }\end{array}$ & 272 & 68.3 \\
\hline $\begin{array}{c}\text { Wont charge for my services but } \\
\text { would be motivated by availability of } \\
\text { incentives }\end{array}$ & 176 & 44.2 \\
\hline Must be paid for my services & 49 & 12.3 \\
\hline Table $2:$ Distrition of Respond & & \\
\hline
\end{tabular}

Table 3: Distribution of Respondents According to Their Perception of and Attitude to VNRBD

In table 3, the various perceptions of the respondents and attitude towards VNRBD are displayed. A large proportion $(93.5 \%)$ was willing to donate blood voluntarily without asking for money if approached, $89.4 \%$ believed that VNRBD should be encouraged while $82.7 \%$ perceived it as safe and lifesaving.

Table 4 shows that $74.1 \%$ of the respondents had ever donated blood while $71.4 \%$ said the blood donation was VNRBD. Whereas 103 had never donated blood in the previous 6 months, 76 (25.8\%) of the 295 who had ever done VNRBD donated once, $11.2 \%$ donated twice while 3 donated thrice. Among the 102 who had never donated blood, 29\% said being busy with school work was the reason for not donating while $26.2 \%$ simply did not feel like donating.

\begin{tabular}{|c|c|c|}
\hline Variables & Frequency (n=398) & Percentage (\%) \\
\hline Ever donated blood & 295 & 74.1 \\
\hline It was voluntary unpaid blood donation & 284 & 71.4 \\
\hline $\begin{array}{c}\text { How many times have you donated blood } \\
\text { (VNRBD) in the last 6 months (N=295) }\end{array}$ & & \\
\hline Once & 76 & 25.8 \\
\hline Twice & 33 & 11.2 \\
\hline Thrice & 3 & 1.0 \\
\hline Main reason for not donating(N=103) & 48 & 26.2 \\
\hline Did not feel like donating & 32 & 17.5 \\
\hline Did not remember to go and donate & 16 & 8.7 \\
\hline Did not have transport money to go donate & 34 & 18.6 \\
\hline Was not reminded & 53 & 29.0 \\
\hline Was busy with school work & & \\
\hline
\end{tabular}

Table 4: Distribution of Respondents According to Practice of VNRBD, and Factors Affecting Practice

In table 5, a significantly greater proportion of males than females showed the correct attitude about VNRBD $(\mathrm{Z}=3.31 ; \mathrm{p}<0.05)$. Similarly, clinical students had significantly more correct knowledge about VNRBD, that their preclinical counterparts. $(\mathrm{Z}=3.54 ; \mathrm{p}<0.05)$

Table 6 shows that a significantly higher proportion of male respondents $(84.4 \%)$ had ever donated blood when compared to their female counterparts $(67.7 \%),(p<0.05)$, in the same way that significantly more males $(83 \%)$ than females $(61.8 \%)$ had ever donated blood on the basis of VNRBD $(p<0.05)$. The same trend was observed for donating blood at least once in the previous 6 months (Males-35.5\% versus females- 19.4\%; $\mathrm{P}<0.05$ ). Furthermore, significantly 
higher proportion of preclinical students (78.4\%) than their clinical counterparts $(66 \%)$ had ever donated blood on the basis of VNRBD $(\mathrm{P}<0.05)$. Similarly, higher proportion of preclinical $(33.8 \%)$ than clinical subjects $(22 \%)$ had donated blood at least once in the last 6 months; $\mathrm{P}<0.05$.

\begin{tabular}{|c|c|c|c|}
\hline $\begin{array}{l}\text { Variables } \\
\text { Gender }\end{array}$ & Correct Knowledge of VNRBD (\%) & SED\% & $\begin{array}{c}\text { P- } \\
\text { value }\end{array}$ \\
\hline Male $(n=218)$ & $142(65.1)$ & \multirow[b]{2}{*}{1.79} & \\
\hline Female $(n=186)$ & $105(56.5)$ & & $\mathrm{p}>0.05$ \\
\hline \multicolumn{4}{|l|}{ Class level } \\
\hline Preclinical $(n=204)$ & $102(50.0)$ & \multirow[b]{2}{*}{3.54} & \multirow[b]{2}{*}{$\mathrm{P}<0.05^{*}$} \\
\hline Clinical $(\mathrm{n}=200)$ & $135(67.5)$ & & \\
\hline Variables & Positive attitude to VNRBD (\%) & SED $\%$ & P-value \\
\hline \multicolumn{4}{|l|}{ Gender } \\
\hline Male $(n=218)$ & $156(71.6)$ & \multirow[b]{3}{*}{3.31} & \multirow[b]{3}{*}{$\mathrm{P}<0.05^{*}$} \\
\hline Female (186) & $104(55.9)$ & & \\
\hline Class level & & & \\
\hline Preclinical (204) & $101(49.5)$ & \multirow[b]{2}{*}{1.70} & \multirow[b]{2}{*}{$\mathrm{P}>0.05$} \\
\hline Clinical (200) & $103(51.5)$ & & \\
\hline
\end{tabular}

Table 5: Gender and Class Level in Relation to Knowledge of and Attitude to VNRBD among Respondents *Statistically Significant

\begin{tabular}{|c|c|c|c|}
\hline $\begin{array}{c}\text { VARIABLES } \\
\text { Gender }\end{array}$ & Ever donated blood (\%) & SED\% & P-value \\
\hline Male (n=218) & $184(84.4)$ & \multirow[b]{2}{*}{3.94} & \multirow[b]{2}{*}{$\mathrm{P}<0.05^{*}$} \\
\hline Female $(n=186)$ & $126(67.7)$ & & \\
\hline Class level & & & \\
\hline Preclinical $(n=204)$ & $162(79.4)$ & \multirow[b]{2}{*}{1.56} & \multirow[b]{2}{*}{$P>0.05$} \\
\hline Clinical $(n=200)$ & $\begin{array}{c}135(67.5) \\
\text { Ever donated on the basis of VNRBD } \\
(\%)\end{array}$ & & \\
\hline $\begin{array}{c}\text { Gender } \\
\text { Male }(\mathrm{n}=218) \\
\end{array}$ & $181(83.0)$ & \multirow[b]{3}{*}{4.85} & \multirow[b]{3}{*}{$\mathrm{P}<0.05^{*}$} \\
\hline Female $(n=186)$ & $115(61.8)$ & & \\
\hline Class level & & & \\
\hline Preclinical $(\mathrm{n}=204)$ & $160(78.4)$ & & \\
\hline Clinical $(n=200)$ & $132(66.0)$ & 2.79 & $\mathrm{P}<0.05^{*}$ \\
\hline & $\begin{array}{c}\text { Donated at least once in the last } 6 \\
\text { months }(\%)\end{array}$ & & \\
\hline \multicolumn{4}{|l|}{ Gender } \\
\hline Male $(n=218)$ & $77(35.3)$ & \multirow{3}{*}{3.36} & \multirow{3}{*}{$\mathrm{P}<0.05^{*}$} \\
\hline Female $(n=186)$ & $36(19.4)$ & & \\
\hline Class level & & & \\
\hline Preclinical $(n=204)$ & $69(33.8)$ & \multirow{3}{*}{2.67} & \multirow{3}{*}{$\mathrm{P}<0.05^{*}$} \\
\hline Clinical $(n=200)$ & $44(22)$ & & \\
\hline *Statistically significant & & & \\
\hline
\end{tabular}

Table 6: Gender and Class Level in Relation to Practice of VNRBD among the Respondents

\section{Discussion}

Four hundred and twenty-two questionnaires were distributed but 404 of them were retrieved with 398 found to be properly filled. The demographics showed that the mean age of the respondents was 24 years. This age places IMSU medical students in apposition to ensure that the WHO goal of ensuring blood supplies is sourced entirely from voluntary non-remunerated blood donors by year 2020 comes to fruition. According to WHO, 38\% of reported voluntary donors are under 25 years of age [12]. Most of the respondents have heard about and infact known the correct meaning of VNRBD. The high level of awareness is similar to the finding by Agrawal A., Tiwari A.K, Ahuja A. And Kalia R5 although in that study, awareness was higher in people with higher educational level. Almost all respondents knew that VNRBD is donation of blood by a willing donor without asking for money. However, when other questions on knowledge of VNRBD are taken into account, only an average of $50 \%$ of the respondents can be said to have possessed right knowledge about 
VNRBD. The high but incomplete knowledge was also found among medical undergraduate students in Pondicherry, India [20].

Most of the respondents had a positive perception about VNRBD considering the high proportions that are willing to donate blood based on VNRBD, cherish this type of donation, opine that is should be practiced by all, assert that it is safe and lifesaving and who agreed that it should be encouraged. Only an average of $6.1 \%$ of the respondents had negative perception about VNRBD. These high levels of perceptions and attitudes are similar to the findings in most other studies [21-24] which however also showed a higher level of knowledge about VNRBD in males than their female colleagues.

The willingness shown by IMSU medical students to be trained as recruiters of VNRB donors, coupled with their high knowledge of VNRBD is a golden opportunity which stakeholders can harness in the drive towards increasing the number of VNRB donors in the country, more so since most of them would be willing to do it without charging money for it.

Most of the respondents (74.1\%) have generally donated blood at least once, with $71.4 \%$ of the donation being on the basis of VNRBD. More than half of the VNRB donors (62.0\%) have not donated blood in the last 6 months, $25.8 \%$ have donated once, and $11.2 \%$ have donated twice while $1 \%$ has donated three times. Although a high percentage of IMSU medical students have ever practiced VNRB donation, yet this practice cannot be said to be optimum. Optimum blood donation presupposes that male donor donate blood four times in a year (that is twice in 6 months) while females donate blood three times in a year and Allain J.P et al [25] opined that 'it is repeat donations which make voluntary nonremunerated blood donation safer'. Only 11.2\% of voluntary blood donors have donated blood twice in the last 6 months despite the high percentage of people that have ever donated blood (74.1\%) and also made the donations on the basis of VNRBD (71.4\%). The low optimum practice of VNRBD was also recorded in other studies [1,21-23]. This tends to be in agreement that good knowledge and attitude towards voluntary non-remunerated blood donation may not necessarily translate to optimum practice of it.

The reasons for not donating blood in the last 6 months included not feeling like donating (26.1\%), not remembering to go and donate (17.4\%), not having transport money to go where they donate blood $(8.7 \%)$, not being reminded (18.5\%) and being busy with school work (29.3\%). As medical students, it is expected that school work could affect practice of blood donation as was seen in another study among both Nigerian and Indian students [1,20] and in line with postulation of Umah, et al [26] that, 'creating opportunity for blood donation may be an important motivating factor for optimum practice of VNRBD by medical students'. Also, reminding the students of the need to donate blood and provision of transport facilities may boost their practice of VNRBD.

\section{Conclusion}

This school-based cross-sectional descriptive study on the knowledge, attitude and practice of voluntary nonremunerated blood donation (VNRBD) among medical students of Imo State University was conducted at the two campuses of the Faculty of Medicine; Owerri and Orlu campuses, housing the Preclinical and Clinical schools respectively with the clinical school being attached to the Imo State University Teaching Hospital, Orlu, Imo State.

The mean age of the medical students of IMSU falls within the age bracket that have been found to be most involved in VNRB donation all over the world. The Imo State University Medical students showed a high but incomplete of knowledge. They also exhibited high positive perception and attitude towards VNRBD. Most Imo State University medical students are willing to be trained as recruiters of prospective VNRB donors from the general population and would not charge any fee for such services and majority of the students have donated blood at least once, with a high proportion of the donations being on the basis of VNRBD. However only a few of them have an optimum practice of VNRB donation.

Tight academic schedules, lack of transportation facilities, not remembering to go and donate blood and not being reminded to go and donate blood accounted for sub-optimum practice of VNRBD by the VNRBD student donors.

\section{References}

i. Salaudeen A G, Odeh E. Knowledge and behavior towards voluntary blood among students of a tertiary institution in Nigeria. Niger J ClinPract[serial online] 2011 \{cited 2014 jul 5\};14:303-7. Available from: http://www.njcponline.com/text.asp?2011/14/3/303/86773

ii. Lowe K C and Ferguson. Benefit and risk perceptions in Transfusion medicine:blood and blood substitutes. Journal of Internal Medicine.2003; Vol.253(5):pgs. 498-507

iii. Hoffbrand A.V and Moss P.A.H. Essential Haematology.6th edition, Wiley-blackwell publishing,Uk, 2011, Pgs 337-341.

iv. Harding A.J. History of blood transfusion - The Institute of Biomedical Science.Available at: https://www.ibms.org/go/nm:history-blood-transfusion. Accessed: 04/09/2014

v. Agrawal A,Tiwari A.K.,Ahuja A.,and Kalra R. Knowledge,Attitude and Practices of People towards voluntary blood donation in Uttarakhand. Asian J Transfus Sci. 2013 Jan-Jun;7(1):59-62

vi. Kowsalya V.,Vijayakumar R.,Chidambaram R.,Srikumar R.,Prabhakar E.,Latha S.,et al. Knowledge, attitude and practice regarding voluntary blood donation among medical students in Puducherry, India. Pakistan Journal of Biological Sciences.2013;16(9):439-442

vii. Di Lorenzo,N.,Tognoni V.,Iezzi L.,and Gaspari A.L. Surgery needs better support from EU. Surg. Endoscopy. 2011;25:339-342

viii. Blood Transfusion in obstetrics, RCOG Green top guideline no. 47:2007;

ix. Agboghoroma 0.C,Emuveyan E:E. Maternal Mortality in Lagos,Nigeria:A ten year review(1986-1995). NigQt J Hosp.Med 1997;7(3):230-233 
x. Garenne M,Bah MD,Cornea P. Risk factors for maternal mortality:A case controlled study in Dakar Hospitals(Senegal). Afric.J ReprodHlth 1997;1(1):14-24

xi. Schantz-Dunn J and Nawal M. The use of Blood in Obstetrics and Gynaecology in the Developing World. Rev ObstetGynaecol. 2011 summer;4(2):86-91

xii. Nilsson Sojka B, Sojka P. The blood donation experience: Perceived physical,psychological and social impact of blood donation on the donor. Vox Sang 2003;84:120-8.

xiii. Olaiya,M.A.,Alakija W.,Ajala A.,Olatunji R.O. Knowlegde,attitudes,beliefs and motivations towards blood donations among blood donors in Lagos, Nigeria. Transfusion Med.,14:13-17

xiv. Van der Poel C.L.,Seifried E., and Schaasberg W. P. "Paying for blood donations:still a risk?".VoxSanguinis 2002;83(4):285-293

xv. "The Melbourne declaration on 100\% voluntary non-remunerated donation of blood and blood products," Composed at World Blood Donor Day.Melbourne,Australia,2009.

xvi. Federal Ministry of Health in Nigeria. Federal Ministry of Health, Policy on blood donation. Nigeria: Federal Government of Nigeria Press,Abuja,Nigeria 2007.

xvii. World Health Organization blood transfusion safety e2008. Available from: http://www.who.int/bloodsafety/voluntary_donation/en/. Last accessed on 11/8/2014.

xviii. World Health Organization. Voluntary Blood Donation,2007. Available from: http://www.who.Int./entity/voluntary blood. Last accessed on 5/9/2014

xix. Daniel WW. Biostatistics: A Foundation for Analysis in the Health Sciences. 1999 7th edition. New York: John Wiley \& Sons.

xx. Bharatwaj R.S.,Vijaya K., and Rajaram P. A Descriptive Study of Knowledge,Attitude and Practice with regard to Voluntary Blood Donation among Medical Undergraduate Students in Pondicherry,India. Journal of Clinical and Diagnostic Research.2012;6(4):602-604

xxi. Ahmed Z, Zafar M, Khan AA, Anjum MU, Siddique MA. Knowledge, Attitude and Practices about Blood Donation among Undergraduate Medical Students in Karachi. J Infect Dis Ther 2014;2:134.

xxii. Nwogoh B.,Aigberadion U., and Nwannadi A.I. Knowledge,Attitude and Practice of Voluntary Blood Donation among Healthcare workers at the University of Benin Teaching Hospital,Benin City,Nigeria.J Blood Transfus. 2013:797-830. doi: 10.1155/2013/797830. Epub 2013 Oct 9Via PubMed

xxiii. Nwogoh B.,Aigberadion U., and Nwannadi A.I. Knowledge,Attitude and Practice of Voluntary Blood Donation among physicians in a tertiary health facility of a developing country.Journal of Blood Transfusion and Immunohaematology 2012;2:4-10

xxiv. Giri A.P.,Phalke D.B.Knowledge and Attitude about Blood Donation amongst undergraduate students of Pravara Institute of Medical Sciences. Original article 2012;5(6):569-573

xxv. Allain J-P,Sarkodie F, Asenso-mensah K,Owusu-ofori S. Relative safety of first-time volunteer and replacement donors in West Africa. Transfusion 2010 Feb 15;50(2);340-343

xxvi. Uma S.,Arun R., and Arumugam P. The Knowledge,Attitude and Practice towards Blood Donation among Voluntary Blood Donors in Chennai,India. Journal of Clinical and Diagnostic Research.2013;7(6):1043-1046 